\title{
The effects of the balance between rumen degradability of crude protein and organic matter and meal frequency on rumen fermentation
}

\author{
Z Shabi, A Arieli, I Bruckental, H Tagari, Y Aharoni, S Zamwell \\ The Hebrew University, Faculty of Agriculture, Rehovot, Israel and Institute of Animal Science, \\ Agriculture Research Organization. The Volcani Center, Bet Dagan and Neve-Yaar, Israel
}

As a surplus of crude protein (CP) in dairy cow rations may have an adverse effect on dairy cow performance, a reduction in excessive $\mathrm{N}$ losses may be achieved by stabilizing fermentation in the rumen. Such improvements may be obtained by a balanced meal frequency schedule and by synchronization of degradable $\mathrm{CP}$ and organic matter $(\mathrm{OM})$ in the rumen.

Four Holstein cows in midlactation with ruminal and abomasal cannulae were studied in a split $4 \times 4$ Latin square trial. Diets of $50 \%$ concentrates contained (on a DM basis) $17 \%$ $\mathrm{CP}, 1.7 \mathrm{Mcal}$ NE, $29 \%$ NDF and were offered in two or four meals, lasting 2 to $3 \mathrm{~h}$. Diet degradability, varied in rumen degradability of OM (HDOM 58 vs LDOM $54 \%$ ), the difference stemming from the use of corn or steamtreated corn grains, and in rumen degradability of CP (HDCP 67 vs LDCP $60 \%$ ), the difference lying in the use of soybean meal or Soypass. The other ingredients, corn silage and vetch hay, were fed in equal amounts. Ruminal samples were taken every $1.5 \mathrm{~h}$ to assess the diurnal pattern of fermentation. Blood urea was sampled at 0,2 and $4 \mathrm{~h}$ post-feeding. Abomasal $O M$ and $C P$ flow was assessed using $\mathrm{Cr}$-mordant as a marker. Difference of effects were based on $\mathrm{P}<0.05 \mathrm{~F}$ ratio.

The ruminal acetate/propionate ratio was 3.5 in HDCP and 3.7 in LDCP. Rumen ammonia (means and coefficients of variation, $\mathrm{CV}$ ) were 15.5 and $16.7 \mathrm{mg} / \mathrm{dl}$ in HDOM and LDOM ; and 17.4 and $14.9 \mathrm{mg} / \mathrm{dl}$ at HDCP and LDCP, respectively. Ammonia levels were 17.0 and $15.3 \mathrm{mg} / \mathrm{dl}$ at four and two meals per day, respectively. Ammonia $\mathrm{CV}$ was 60.8 and $52.7 \%$ with LDCP and HDCP, respectively. With two or four meals per day, CVs of ammonia were 63.8 and $49.7 \%$, respectively. Blood N-urea was 18.4 and $21.5 \mathrm{mg} / \mathrm{dl}$ in HDOM and LDOM. Blood N-urea was 16.4 and $20.7 \mathrm{mg} / \mathrm{dl}$ before the meal at 2 and 4 meals per day. Under these treatments, blood $\mathrm{N}$-urea was 22.2 and $18.3 \mathrm{mg} / \mathrm{dl} 2 \mathrm{~h}$ after meal, and 22.8 and $19 \mathrm{mg} / \mathrm{dll} 4 \mathrm{~h}$ after meals. Abomasal CP flows were 2.6 and $2.8 \mathrm{~kg} / \mathrm{d}$ in HDCP and LDCP, and 2.9 and $2.5 \mathrm{~kg} / \mathrm{d}$ in HDOM and LDOM, respectively.

It is concluded that rumen fermentation may be controlled by means of a balanced supply of $\mathrm{OM}$ and $\mathrm{CP}$, or by meal frequency. 